\title{
Artikel
}

\section{De verdachte is dood, leve het strafproces?}

\author{
De straf(proces)rechtelijke gevolgen van de dood van de verdachte of veroordeelde nader \\ bezien
}

Mr. dr. E.M. (Eelco) Moerman en mr. dr. J.H.B. (Joeri) Bemelmans*

\section{NTS 2020/54}

\section{Inleiding}

'In this world nothing can be said to be certain, except death and taxes.' Bij nader inzien blijkt zelfs op de onvermijdelijkheid van belastingen soms nog wel wat af te dingen. ${ }^{2}$ De dood is echter onontkoombaar, uiteraard ook voor verdachte en veroordeelde natuurlijke personen. ${ }^{3}$ Overlijdt een verdachte voordat hij onherroepelijk is veroordeeld of een onherroepelijk veroordeelde voordat de tenuitvoerlegging van de aan hem opgelegde sanctie is voltooid, dan leidt dit sterven tot

* Mr. dr. E.M. Moerman en mr. dr. J.H.B. Bemelmans zijn beiden medewerker bij het Wetenschappelijk Bureau van de Hoge Raad. Deze bijdrage is op persoonlijke titel geschreven.

1. Aldus Benjamin Franklin in een brief aan Jean-Baptiste le Roy in 1789 over de toekomst van de toen nieuwe Amerikaanse Constitutie. Franklin ontleende de zegswijze vermoedelijk aan oudere literatuur.

2. Vgl. bijv. www.nos.nl/artikel/2285715-shell-betaalt-geenwinstbelasting-in-nederland.html over een Nederlands-Britse multinational die in Nederland geen winstbelasting afdraagt.

3. Buiten beschouwing blijft de ontbonden en daarmee 'overleden' rechtspersoon, zie daarover bijv. HR 2 oktober 2007, ECLI:NL:HR: 2007:BA5825, NJ 2008/550 m.nt. Mevis en voor een kritische analyse van de rechtspraak van de Hoge Raad A.L.J. van Strien, De rechtspersoon in het strafproces. Een onderzoek naar de procesrechtelijke aspecten van de strafbaarheid van rechtspersonen (diss. Leiden), Den Haag: Sdu Uitgeverij 1996, p. 66-73. een nieuwe straf(proces)rechtelijke situatie. ${ }^{4}$ De dood van de verdachte of veroordeelde doet de rechten tot strafvervolging en tot strafexecutie niet in alle gevallen volledig teniet. Sommige strafrechtelijke straffen en maatregelen kunnen ook na overlijden nog worden opgelegd of tenuitvoergelegd. In deze bijdrage onderzoeken wij of het Nederlandse strafprocesrecht wat betreft de straf(proces)rechtelijke situatie na het overlijden van de verdachte of veroordeelde een coherente en voldoende doordachte regeling kent. ${ }^{5}$

Allereerst wordt kort stilgestaan bij de vraag wanneer iemand juridisch eigenlijk dood is, hoe zich dat in rechte laat vaststellen en hoe wordt omgegaan met feitelijke onzekerheid of achteraf bezien onjuiste vaststellingen met betrekking tot het overlijden (par. 2). Daarna gaan wij dieper in op de hoofdregel dat de rechten tot strafvervolging en strafexecutie vervallen door de dood van de verdachte/veroordeelde en identificeren wij bestaansredenen voor dit uitgangspunt en de beperkingen die dit stelt aan de ruimte om na overlijden nog strafrechtelijke sancties op te leggen en/of te executeren (par. 3). Vervolgens analyseren wij de in het geldende recht bestaande uitzonderingen op het uitgangspunt dat vervolging en bestraffing van een overledene niet mogelijk zijn (par. 4). In par. 5 zullen de consistentie en

4. De consequenties van het overlijden van andere procesactoren worden niet besproken. $\mathrm{Vgl}$. over de gevolgen van de dood van een rechter bijv. HR 3 april 2018, ECLI:NL:HR:2018:501, NJ 2018/199 en van het overlijden van een benadeelde partij bijv. HR 15 april 2014, ECLI:NL:HR:2014:917, NJ 2014/243.

5. Voor een bredere 'doorlichting' van het stelsel op dit punt pleit J. de Hullu, Materieel strafrecht. Over algemene leerstukken van strafrechtelijke aansprakelijkheid naar Nederlands recht, Deventer: Kluwer 2018, p. 118. 
wenselijkheid van de bestaande hoofdregel en de daarop geldende uitzonderingen nader worden afgewogen. Wij sluiten af met een korte conclusie (par. 6).

\section{Het juridisch doodsbegrip en de vaststelling van de dood in rechte}

Het Nederlands recht kent geen algemeen juridisch doodsbegrip. ${ }^{6}$ Of en wanneer iemand is gestorven, is voornamelijk overgelaten aan de inzichten van de medische professie. ${ }^{7}$ Zo draagt de 'Richtlijn Lijkschouw voor behandelend artsen' op om de dood vast te stellen door onder meer hart en longen te beluisteren en de pupilreactie te beoordelen. ${ }^{8}$ Is de behandelend arts ervan overtuigd dat de dood is ingetreden ten gevolge van een natuurlijke oorzaak, dan kan hij een overlijdensverklaring afgeven. ${ }^{9}$ Op basis van de overlijdensverklaring wordt door een ambtenaar van de burgerlijke stand een akte van overlijden opgemaakt. ${ }^{10}$ Deze akte is het meest geëigende middel om wettig aan te tonen dat een indivi$\mathrm{du}$ is overleden. Daarmee kan onzekerheid over leven en dood worden voorkomen. ${ }^{11}$ Dat is ook nodig, niet in de laatste plaats omdat het overlijden van een persoon in allerlei rechtsgebieden juridische consequenties heeft. ${ }^{12}$

6. In art. 14 van de Wet op de orgaandonatie wordt een juridisch doodsbegrip gegeven, namelijk hersendood, maar daarmee heeft de wetgever uitdrukkelijk niet beoogd het vaststellen van de dood in zijn algemeenheid te regelen. Zie Kamerstukken // 1991/92, 25 358, nr. 3, p. 43.

7. Vgl. H.J.J. Leenen e.a., Handboek gezondheidsrecht, Den Haag: Boom juridisch 2017, p. 46-47 voor een bespreking van zelfregulering in de zorg. Vgl. ook nogmaals art. 14 van de Wet op de orgaandonatie, waarin verwezen wordt naar de 'volgens de laatste stand van de wetenschap geldende methoden en criteria voor het vaststellen van de hersendood door een ter zake kundige arts'. Deze state of the art is neergelegd in het Besluit Hersendoodprotocol (Stb. 1997, 306, laatst gewijzigd bij Stb. 2017, 74).

8. 'Richtlijn Lijkschouw voor behandelend artsen. Werkwijze en samenwerking met gemeentelijk lijkschouwers en politie', opgesteld door het Nederlands huisartsen genootschap, Utrecht juni 2016, p. 10. Overigens volgt uit de wet niet dat enkel artsen de dood mogen vaststellen, al zal dit voor de lijkbezorging wel noodzakelijk zijn. Althans meestal, want vgl. art. 22 Besluit op de lijkbezorging (Stb. 1997, 647, laatst gewijzigd bij Stb. 2019, 46), dat de gezagvoerder van een schip de bevoegdheid geeft om een stoffelijk overschot overboord te doen zetten zonder dat overleg is gevoerd met een arts.

9. Zie Kamerstukken // 2014/15, 30 696, nr. 39, p. 7-8 voor een wetshistorische schets van de Wet op de lijkbezorging.

10. Zie art. 1:19f e.v. BW. Overigens kan op grond van art. 1:19k BW ook een bewijs van in leven zijn ('attestatie de vita') worden aangevraagd om in het buitenland aan te kunnen tonen dat de desbetreffende persoon in leven is.

11. Vgl. J. de Boer, Mr. C. Assers Handleiding tot de beoefening van het Nederlands Burgerlijk Recht. 1. Personen- en familierecht, Deventer: Kluwer 2010/27.

12. Ter illustratie noemen wij de oplegging van een civielrechtelijke dwangsom (vgl. art. $611 \mathrm{Rv}$ ), verschuldigde belastingrente (vgl. art. $30 \mathrm{~g}$ lid 2 onder a en lid 4 AWR) en familierechtelijke verhoudingen (vgl. art. 1:199 onder b BW).
Zulke onzekerheid bestaat in juridische procedures soms toch, bijvoorbeeld omdat iemand wordt vermist, ${ }^{13}$ of vanwege de gebrekkige bewijskracht van de bron van de informatie dat de betrokken persoon zou zijn overleden. In een strafzaak waarin de advocaat-generaal bij de Hoge Raad op basis van een fotokopie van een buitenlandse overlijdensverklaring met Engelse vertaling en beelden van een begrafenisstoet concludeerde dat de verdachte was overleden, kwam de Hoge Raad tot een ander oordeel. Op de juistheid van de betreffende overlijdensverklaring kon niet zonder meer worden afgegaan. Daarbij betrok de Hoge Raad de twijfel over de herkomst en de betrouwbaarheid van de akte en de resultaten van het onderzoek hieromtrent. De strafvervolging kon daarom worden voortgezet. ${ }^{14}$ Als uitgangspunt heeft dan ook te gelden dat bij twijfel over de dood de strafprocedure voortgaat. Dat is bijvoorbeeld van belang in het kader van de berechting van (vermeende) Syriëgangers waarvan onduidelijk is of zij in het strijdgebied zijn omgekomen. ${ }^{15}$ Uiteraard behoeft op een overlijdensakte niet te worden afgegaan als het daarin verklaarde evident niet klopt. Toen een verdachte op basis van een - naar achteraf bleek: valse - buitenlandse overlijdensakte dood was verklaard, kon aan zijn registratie als overledene volgens de Hoge Raad voorbij worden gegaan, aangezien de verdachte in persoon op de zitting was verschenen. ${ }^{16}$

Overigens kunnen onjuiste vaststellingen van het al dan niet overlijden in strafzaken veelal worden hersteld. Indien het openbaar ministerie niet-ontvankelijk in de strafvervolging is verklaard en de verdachte achteraf toch nog in leven blijkt, is een nieuwe vervolging mogelijk. Alleen na een materiële einduitspraak (vrijspraak, ontslag van alle rechtsvervolging of veroordeling) blokkeert artikel 68 lid $1 \mathrm{Sr}$ een tweede vervolging. ${ }^{17}$ Andersom kan zich de situatie voordoen dat een onherroepelijk veroordeelde later blijkt reeds te zijn

13. Uit de achttiende titel van het Eerste Boek van het Burgerlijk Wetboek volgt dat een vermissing niet op één lijn kan worden gesteld met een overlijden. Afhankelijk van de mate van waarschijnlijkheid van overlijden kan na een vermissingsperiode van nul tot vijf jaar aan de rechter worden verzocht om het overlijden uit te spreken. Zie daarover nader M. Jonker, W.M. Schrama \& C.G. Jeppesen de Boer, 'Onderzoek naar juridische gevolgen van vermissing; op zoek naar antwoorden', Tijdschrift voor Familie- en Jeugdrecht 2018/47. Bij gebrek aan een (eigen) strafrechtelijk kader, wordt in de schaarse strafrechtspraak over dit onderwerp aansluiting gezocht bij deze civiele regeling, zie bijv. Hof Den Haag 11 november 2015, ECLI:NL:GHDHA:2015:3138 en Rb. Den Haag 10 december 2015, ECLI:NL:RBDHA:2015:14365.

14. HR 7 oktober 2014, ECLI:NL:HR:2014:2911.

15. Zie bijv. Hof Den Haag 11 november 2015, ECLI:NL:GHDHA: 2015:3138.

16. HR 26 mei 1987, kenbaar uit EHRM 26 mei 1993, nr. 13645/88, ECLI:NL:XX:1993:AD1889, NJ 1993/466 m.nt. Alkema (Bunkate/ Nederland)

17. Vgl. HR 20 februari 2007, ECLI:NL:HR:2007:AZ4757 over een (andere) niet-ontvankelijkheid van het openbaar ministerie. Zie in deze zin ook De Hullu 2018, p. 547 en A.J.M. Machielse 'art. 68 Sr' in: J.W. Fokkens, E.J. Hofstee \& A.J.M. Machielse (red.), Wetboek van Strafrecht - Noyon, Langemeijer, Remmelink, Deventer: Wolters Kluwer, aant. 1. Ook internationale verdragsbepalingen over het beginsel ne bis in idem (zie de tekst van art. 4 P7 EVRM, art. 14 lid 7 IVBPR en art. 50 EU-handvest) verbieden een tweede vervolging alleen als de eerste tot een inhoudelijke einduitspraak heeft geleid. 
gestorven vóórdat de laatste einduitspraak in zijn zaak is gewezen. Deze omstandigheid kan een zogeheten novum en daarmee een grond voor herziening opleveren. ${ }^{18} \mathrm{Na}$ het overlijden kan op grond van artikel $458 \mathrm{~Sv}$ de procureur-generaal of een van de in dat wetsartikel genoemde nabestaanden een aanvraag tot herziening indienen, op grond waarvan het openbaar ministerie alsnog niet-ontvankelijk kan worden verklaard. ${ }^{19}$

\section{Het verval van de rechten tot strafvervolging en sanctie-executie bij overlijden}

Artikel $69 \mathrm{Sr}$ bepaalt dat het recht tot strafvordering vervalt door de dood van de verdachte. Is de zaak bij een strafrechter aanhangig, ${ }^{20}$ dan brengt het overlijden van de verdachte in ieder stadium van de procedure mee dat deze strafrechter - eventueel met vernietiging van een eerdere uitspraak ${ }^{21}$ - het openbaar ministerie in de strafvervolging niet-ontvankelijk verklaart. Is aan de overledene bij onherroepelijke uitspraak van de strafrechter of bij strafbeschikking een strafrechtelijke sanctie opgelegd dan geldt het bepaalde in artikel $6: 1: 21 \mathrm{~Sv}^{22}$ Deze bepaling houdt in dat een straf of maatregel niet ten uitvoer wordt gelegd na de dood van de veroordeelde. ${ }^{23}$

De dood van een verdachte of veroordeelde zet in beginsel dus een punt achter zowel de strafvervolging als de executie van opgelegde strafrechtelijke sancties. Dit behoefde volgens de wetgever van 1886 weinig

18. Zie bijv. HR 3 maart 1987, ECLI:NL:HR:1987:AB8325, NJ 1987/865. Minder juist lijkt ons de suggestie van Machielse (A.J.M. Machielse 'art. 69 Sr' in: J.W. Fokkens, E.J. Hofstee \& A.J.M. Machielse (red.), Wetboek van Strafrecht - Noyon, Langemeijer, Remmelink, Deventer: Wolters Kluwer, aant. 2) en Van Dorst (A.J.A. van Dorst, 'Revisie post mortem', in: G. Knigge e.a. (red.), Gehoord de Procureur-Generaal (Fokkens-bundel), Deventer: Wolters Kluwer 2016, p. 73 om bij een (veroordelend) vonnis in dat geval een herstelbeslissing te overwegen, omdat dan geen sprake is van een onmiddellijk kenbare fout, verschrijving of verrekening in de uitspraak. Zie over de gevallen waarin een herstelbeslissing uitkomst biedt nader J.H.B. Bemelmans, F.C.W. de Graaf \& E.M. Moerman, 'Herstelbeslissingen van de feitenrechter wettelijk geregeld: een verbetering?', DD 2019/54.

19. Zie over deze voorziening kritisch Van Dorst 2016

20. Of het strafrecht een wettelijke remedie kent als de verdachte ná een einduitspraak overlijdt nog vóórdat die einduitspraak onherroepelijk wordt en voordat hij tegen de uitspraak een rechtsmiddel heeft aangewend, is een vraag die in de schijnwerpers is komen te staan naar aanleiding van het overlijden van de - na vrijspraak in eerste aanleg - in hoger beroep wegens moord veroordeelde Joey D. (Hof Den Bosch 21 januari 2020, ECLI:NL:GHSHE:2020:159), die binnen de cassatietermijn overleed.

21. Anders: Hof Den Haag 30 augustus 2018, ECLI:NL:GHDHA:2018:2527, NJ 2019/292 m.nt. Mevis.

22. Art. 6:1:21 Sv is per 1 januari 2020 (Stb. 2017, 82) de opvolger van art. $75 \mathrm{Sr}$. De strekking van de bepaling is niet gewijzigd.

23. De bepaling bevat een uitzondering voor de onherroepelijke ontnemingsmaatregel, zie daarover hierna par. 4.3. toelichting: 'dat (...) spreekt van zelf' ${ }^{24}$ Die veronderstelde vanzelfsprekendheid valt te betwisten. Er zijn immers ook belangen die tegen verval van het vervolgings- en executierecht pleiten. Een slachtoffer kan bijvoorbeeld gebaat zijn bij verdere waarheidsvinding of erkenning voor het begaan van het feit, de benadeelde partij ziet haar schadevergoedingsvordering door het overlijden sneuvelen en dient zich ter vergoeding te wenden tot de civiele rechter en aan de overleden verdachte kan een vrijspraak worden ontzegd. ${ }^{25}$

Toch bestaan voor het geldende uitgangspunt ten minste vier goede redenen. De minister noemde destijds al het argument dat 'alle straf persoonlijk moet zijn' ${ }^{26}$ Of, zoals het EHRM het tegenwoordig formuleert: 'It is a fundamental rule of criminal law that criminal liability does not survive the person who has committed the criminal act. ${ }^{27}$ Oplegging van een geldboete aan de erfgenamen wegens een door de overledene begaan strafbaar feit achtte het Europese Hof een criminal charge en leverde een schending op van artikel 6 lid 2 EVRM. Deze opvatting past bij het in Nederland heersende strafconcept en in het bijzonder bij het daarmee verbonden beginsel 'geen straf zonder schuld'. Dit fundamentele uitgangspunt van materieel strafrecht verzet zich ertegen een persoon aansprakelijk te houden voor de gedragingen van een ander, bij wijze van risicoaansprakelijkheid, dus zonder dat een eigen verwijtbare gedraging van die persoon komt vast te staan. ${ }^{28}$ Het is daarmee een krachtig argument tegen vererving van strafrechtelijke aansprakelijkheid en/of van de opgelegde straf. ${ }^{29}$ De rechtspraak van de Hoge Raad over witwassen door het aanvaarden van een criminele nalatenschap sluit daarbij aan. Onder omstandigheden is strafvervolging van erfgenamen wegens witwassen weliswaar mogelijk, maar dan moet de erfgenaam zelf (ten minste voorwaardelijk) opzet erop hebben dat de door hem verkregen goederen uit misdrijf afkomstig zijn én moet hij het oogmerk hebben over die goederen de feitelijke zeggenschap te gaan uitoefenen. ${ }^{30}$ Als dat het geval is,

24. H.J. Smidt, Geschiedenis van het Wetboek van Strafrecht, Eerste deel, tweede druk, J.W. Smidt, Haarlem: Tjeenk Willink 1891, p. 508.

25. Zie over dergelijke belangen ook Th.W. van Veen, 'Rekwirant overleden', DD 1972, p. 466-467. In 2015 vroeg de advocaat Meijering het gerechtshof Amsterdam zich in het liquidatieproces uit te spreken over de schuld van zijn inmiddels overleden cliënt Ali A., zie www.nos.nl/ artikel/2013640-advocaat-wil-oordeel-over-vermoorde-verdachte.html.

26. Smidt 1891, p. 508.

27. Zie o.a. EHRM 29 augustus 1997, nr. 19958/92, par. 48 (A.P., M.P. en T.P./Zwitserland); EHRM 29 augustus 1997, nr. 20919/92, par. 53 (E.L., R.L. en J.O.-L./Zwitserland); EHRM 10 april 2012, nr. 20496/02, par. 51 (Silickiene/Litouwen); EHRM 12 april 2012, nr. 18851/07, par. 77 (Lagardère/Frankrijk) en EHRM (GK) 28 juni 2018, nrs. 1828/06 e.a. (G.I.E.M. e.a./Italië).

28. Zie daarover o.a. E.H.A. van Luijk, Het schuldbeginsel in het Nederlandse strafrecht (diss. Groningen), Ridderkerk: Ridderprint 2015.

29. Vgl. in dezelfde zin De Hullu 2018, p. 118: 'het algemene uitgangspunt [moet] overeind (...) blijven dat de strafrechtelijke aansprakelijkstelling en bestraffing persoonlijk van aard zijn, bepaald door gedrag en schuld van de betrokken natuurlijke persoon en daardoor verbonden met diens leven'. Vgl. ook T. Kooijmans, Op maat geregeld (diss. Rotterdam), Deventer: Kluwer 2002, p. 274.

30. HR 5 september 2006, ECLI:NL:HR:2006:AU6712, NJ 2006/612 m.nt. Borgers. 
kan de erfgenaam een dusdanig eigen verwijt worden gemaakt dat strafrechtelijke aansprakelijkheid wegens misdrijf kan worden gerechtvaardigd.

Strafrechtelijke aansprakelijkheid en straf worden dus niet geërfd, maar daarmee is nog niet verklaard waarom ook de vervolging van de overledene zelf dient te worden gestaakt. Een eerste reden daarvoor (en tweede grond voor het in art. $69 \mathrm{Sr}$ en 6:1:21 Sv neergelegde uitgangspunt) is van strafprocessuele aard. Het recht op een eerlijk strafproces omvat onder meer het recht van de verdachte om zelf een proceshouding en een advocaat te kiezen, bij de berechting van zijn zaak aanwezig te zijn, het recht aan die behandeling daadwerkelijk deel te nemen door over de beschuldiging te worden gehoord en die beschuldiging eventueel tegen te spreken. Het EHRM is van oordeel dat '[a] trial of a dead person inevitably runs counter to the above principles, because by its very nature it is incompatible with the principle of the equality of arms and all the guarantees of a fair trial. $^{31}$

Een aspect van het recht op een eerlijk proces dat na het overlijden van de verdachte of veroordeelde een belangrijke beperking vormt op de ruimte voor de oplegging en tenuitvoerlegging van sancties is de in onder meer artikel 6 lid 2 EVRM neergelegde onschuldpresumptie. De onschuldpresumptie en de rechtspraak van het EHRM daarover verzetten zich onder meer ertegen om iemand van wie in de strafprocedure de schuld aan een strafbaar feit (nog) niet is vastgesteld, in een aan die strafprocedure gelieerde procedure te behandelen alsof hij aan dit feit wel schuldig is. ${ }^{32}$ Dit betekent dat het stranden van de strafvervolging van een overledene als bijkomende consequentie heeft dat hij ook in andere procedures niet mag worden bejegend als schuldig aan het feit waarvan hij werd verdacht. In hoeverre ruimte bestaat om van een niet-veroordeelde na afloop van zijn strafzaak nog de betrokkenheid bij een strafbaar feit aan te nemen, is sterk afhankelijk van het lot van de desbetreffende strafprocedure. Is de voormalige verdachte vrijgesproken van het strafbare feit, dan hanteert het EHRM een strenge lijn: resterende verdenkingen mogen dan niet meer worden uitgesproken. Eindigt het strafproces met een zogenoemde discontinuation, dan is het uiten van verdenkingen (voicing of suspicions) in de regel wel toegestaan, maar wordt de onschuldpresumptie geschonden als uitingen in feite inhouden dat de verdachte schuldig is aan het betreffende feit. ${ }^{33}$

31. EHRM 27 augustus 2019, nrs. 32631/09 en 53799/12, par. 281 (Magnitskiy e.a./Rusland). Vgl. in deze zin ook EHRM 8 april 2008, nr. 7170/02, par. 109 (Grădinar/Moldavië): 'The Court has serious reservations in respect of a legal system allowing the trial and conviction of deceased persons, given the obvious inability of such persons to defend themselves.'

32. Zie daarover uitvoeriger J.H.B. Bemelmans, Totdat het tegendeel is bewezen (diss. Nijmegen), Deventer: Wolters Kluwer 2018, p. 263 e.v.

33. Zie voor dit onderscheid onder meer EHRM 25 augustus 1993, nr. 13126/87/87, NJ 1994/1 m.nt. Knigge (Sekanina/Oostenrijk); EHRM (GK) 12 juli 2013, nr. 25424/09, EHRC 2013/219 m.nt. Bemelmans, par. 103 (Allen/Verenigd Koninkrijk) en de verwijzingen naar EHRMrechtspraak bij Bemelmans 2018, p. 315 e.v.
Zo'n discontinuation is aan de orde als het strafproces zonder inhoudelijke einduitspraak definitief wordt beëindigd. ${ }^{34}$ Ook de niet-ontvankelijkheid vanwege de dood van de verdachte als slotstuk van de strafzaak, betreft een discontinuation ${ }^{35}$ In een aan de strafzaak gerelateerde procedure mag nadien dus wel van resterende verdenkingen blijken, maar mag geen schuldoordeel worden uitgesproken. Is de verdachte niet strafrechtelijk vervolgd in die zin dat hij niet charged with a criminal offence is geweest, dan staat artikel 6 lid 2 EVRM aan een schuldoordeel niet in de weg. Het EHRM acht de verdragsbepaling dan niet van toepassing. ${ }^{36}$

Daarnaast noemt het EHRM als argument tegen de berechting van de overledene dat de eventuele bestraffing niet meer tot de mogelijkheden behoort: 'it is selfevident that it is not possible to punish an individual who has died, and to that extent at least the criminal justice process is stymied. Any punishment imposed on a dead person would violate his or her dignity. ${ }^{37}$ Zonder zich tot mensonterende sancties te verlagen, is tenuitvoerlegging van de straf onder de overledene zelf inderdaad niet meer voorstelbaar. Hooguit kunnen zijn erfgenamen worden getroffen door op zijn nalatenschap vermogenssancties te executeren. Sommige strafdoelen, in elk geval die van vergelding en speciale preventie, worden met een postume veroordeling niet langer bevorderd. Daarmee verliest de strafvervolging in belangrijke mate haar zin. ${ }^{38}$

Een vierde grond voor het uitgangspunt van de artikelen $69 \mathrm{Sr}$ en 6:1:21 Sv kan in onze ogen worden ontleend aan het adagium lites finiri oportet (geschillen moeten tot een eind komen). $\mathrm{Nu}$ het recht tot strafvervolging op de voet van artikel 70 lid $2 \mathrm{Sr}$ niet in alle gevallen verjaart, is de dood van de verdachte soms het enige dat belet dat de mogelijkheid van een strafvervolging - en daarmee

34. Daaronder valt dus naast de vroegtijdige beëindiging van de strafzaak vanwege een sepot ook een negatief antwoord op een van de vragen van art. 348 Sv, zie bijv. EHRM 28 oktober 2003, nr. 44320/98, NJ 2004/261 (Baars/Nederland), waarin het openbaar ministerie niet-ontvankelijk was verklaard wegens ernstige overschrijding van de redelijke termijn.

35. Vgl. EHRM 25 augustus 1987, nr. 10300/83 (Nölckenbockhoff/Bondsrepubliek Duitsland) (geen finding of guilt, geen schending) en EHRM 10 januari 2012, nr. 33468/03 (Vulakh/Rusland) (wel finding of guilt, wel een schending). Het oordeel van de belastingkamer van de Hoge Raad van 6 juli 2018, ECLI:NL:HR:2018:1106, BNB 2018/169 m.nt. De Bont geeft naar ons inzicht een te beperkte uitleg aan deze EHRMrechtspraak. Onder discontinuation moet immers meer worden verstaan dan enkel de seponering wegens gebrek aan bewijs en voor de ondergrens daarvan is niet beslissend of een inhoudelijk oordeel over de (on)schuld van de verdachte is geveld. leder einde van de strafzaak dat geen acquittal behelst, is in principe een discontinuation. Kortom, ook indien het recht tot strafvervolging gedurende de vervolging is vervallen wegens het overlijden van de verdachte dient de (belasting)rechter zich nadien van een schuldoordeel te onthouden.

36. Bemelmans 2018, p. 270-277.

37. EHRM 27 augustus 2019, nrs. 32631/09 en 53799/12, par. 281 (Magnitskiy e.a./Rus/and).

38. Vgl. iets stelliger G.J.M. Corstens, Het Nederlands strafprocesrecht, bewerkt door M.J. Borgers \& T. Kooijmans, Deventer: Wolters Kluwer 2018, p. 221: 'Het vervolgingsrecht kan dan immers niet meer op zinvolle wijze worden geëffectueerd.' 
ook bijvoorbeeld die van een artikel $12 \mathrm{~Sv}$-procedure tot in lengte der dagen blijft voortbestaan.

\section{Uitzonderingen: oplegging en tenuitvoerlegging van strafrechtelijke sancties na overlijden}

4.1 Verbeurdverklaring na overlijden

Artikel $33 \mathrm{Sr}$ bepaalt dat de bijkomende straf van verbeurdverklaring kan worden uitgesproken bij veroordeling wegens een strafbaar feit. Normaliter staat artikel 69 $\mathrm{Sr}$ aan de oplegging van een verbeurdverklaring na overlijden dan ook in de weg. Artikel 16 Wet op de economische delicten (hierna: WED) bevat echter een bijzondere regeling die het mogelijk maakt om in geval van economische delicten na overlijden van de betrokkene in beslag genomen voorwerpen toch nog verbeurd te verklaren..$^{39}$ Daarvoor gelden als voorwaarden dat aannemelijk is dat de overledene zich schuldig heeft gemaakt aan een economisch delict en dat in zijn zaak nog geen onherroepelijke uitspraak is gedaan. Een opgelegde verbeurdverklaring wegens een economisch delict kan - in afwijking van artikel 6:1:21 $\mathrm{Sv}$ - na overlijden nog worden geëxecuteerd (art. 13 WED). Een stevige onderbouwing voor de regeling in artikel $16 \mathrm{WED}$ is in de wetsgeschiedenis niet terug te vinden: 'het ligt (...) niet voor de hand dat de erfgenamen zonder meer gevrijwaard zijn van de schulden die een overledene nalaat' en 'de voordelen, door het delict behaald, behoren (...) niet aan de erfgenamen van de veroordeelde ten goede te komen', zo luidden de beweegredenen voor deze bijzondere bepaling. ${ }^{40} \mathrm{Zij}$ wordt wel in verband gebracht met een van doelstellingen van de WED, te weten 'herstel van nadeel, geleden door de gemeenschap als gevolg van economische delicten en ontneming van uit het begaan van die delicten verworven voordelen'. ${ }^{41}$

Deze bijzondere regeling is bekritiseerd. Volgens Den Hartog kan uit de EHRM-rechtspraak, in het bijzonder de zaken A.P., M.P. en T.P. tegen Zmitserland en E.L., R.L. en 7.O.-L. tegen Zmitserland, worden afgeleid dat de betreffende bepalingen uit de WED in strijd zijn met artikel 6 lid 2 EVRM. ${ }^{42} \mathrm{Zij}$ hecht veel waarde aan de omstandigheid dat de verbeurdverklaring, evenals de

39. Ook maakt art. 16 WED het mogelijk om de onrechtmatige toestand terug te draaien, zie daarover hierna par. 4.2.

40. Respectievelijk Kamerstukken // 1989/90, 21 504, nr. 3, p. 10 en Kamerstukken I/ 1947/48, 603, nr. 3, p. 18.

41. F. Hollander, Wet op de economische delicten. Commentaar op de wet van 22 juni 1950 Staatsblad K 258, Arnhem: S. Gouda Quint/D. Brouwer \& Zoon 1952, p. 111

42. A. den Hartog, 'De nalatenschap van de verdachte. Enige opmerkingen naar aanleiding van EHRM 29 augustus 1997, E.L., R.L. en J.O.-L. tegen Zwitserland', DD 1998, p. 120-121, met verwijzingen naar EHRM 29 augustus 1997, nr. 19958/92 (A.P., M.P. en T.P./Zwitserland), respectievelijk EHRM 29 augustus 1997, nr. 20919/92 (E.L., R.L. en J.O.L./Zwitserland) boeteoplegging in de twee Zwitserse zaken, een punitieve sanctie (criminal charge) betreft. Dat karakter lijkt ons inderdaad geen punt van discussie. Naar Nederlands recht wordt de verbeurdverklaring immers als straf beschouwd. Het strafkarakter betreft ook een aspect dat in de Zwitserse zaken van belang was. Maar die enkele omstandigheid draagt nog niet de conclusie dat toepassing van artikel $16 \mathrm{WED}$ het EVRM schendt. In de Zwitserse zaken stonden de mensenrechten van de erfgenamen centraal; dat zij strafrechtelijk aansprakelijk werden gesteld voor door de erflater begane feiten en/of daarvoor werden bestraft, was ontoelaatbaar. In het kader van artikel 16 WED is dat niet zonder meer het geval. De verbeurdverklaring wordt niet uitgesproken tegenover erfgenamen, maar over een reeds in beslag genomen voorwerp. Van een schuldvaststelling of aansprakelijkstelling ten laste van de erfgenamen is daarmee nog niet per definitie sprake, al schuurt oplegging van een straf na overlijden daar wel dicht tegenaan. ${ }^{43}$

Een andere vraag is hoe artikel 16 WED zich verhoudt tot de onschuldpresumptie van de overleden verdachte zelf. Aangezien de verbeurdverklaring een strafkarakter heeft en mede daarom een criminal charge is, komt de vraag op of de verdachte met de oplegging van die straf niet alsnog als schuldige wordt angemerkt. Ervan uitgaande dat de vervolging van de verdachte voor zijn overlijden is angevangen, anders is artikel 6 lid 2 EVRM immers niet van toepassing, zal de verenigbaarheid met die verdragsbepaling mede afhangen van de door de rechter in zijn beslissing gekozen woorden. Het vereiste van artikel 16 WED dat aannemelijk moet zijn dat de overledene het feit heeft begaan, zal de rechter moeten aangrijpen om zich van (ontoelaatbare) schuldvaststellingen ten aanzien van de overledene te onthouden. Vaststelling dat de overledene het betreffende feit heeft begaan, is dus niet vereist en moet worden vermeden. Met de aannemelijkheid als maatstaf kan de rechter in zijn beslissing blijven binnen de wel geoorloofde sfeer van voicing suspicions.

\subsection{Herstel van een wederrechtelijke situatie}

Op basis van artikel 16 WED kan, naast de verbeurdverklaring, ook de in artikel 8 onder c WED genoemde maatregel worden opgelegd. Deze maatregel houdt de verplichting in tot verrichting van hetgeen wederrechtelijk is nagelaten, tenietdoening van hetgeen wederrechtelijk is verricht en/of verrichting van prestaties tot het goedmaken van een en ander. ${ }^{44}$ Dwang om op eigen kosten de onrechtmatige situatie terug te draaien, kan op een overleden persoon uiteraard niet worden uitgeoefend. Artikel 16 WED bepaalt om die reden dat de betreffende maatregel ten laste van de boedel kan worden opgelegd. Of het in artikel 33 WED neergelegde

43. Een parallel kan getrokken worden met EHRM 6 juni 2006, nr. 6301/05 (The estate of Nitschke/Duits/and): dat een bij leven aan de betrokkene zelf opgelegde geldboete na overlijden op de nalatenschap in mindering werd gebracht, leverde geen verdragsschending op.

44. Zie nader D.R. Doorenbos, Schets van het economisch strafrecht, Deventer: Wolters Kluwer 2015, p. 104 e.v. 
economische delict van niet-naleving van deze maatregel zich ook uitstrekt over de erfgenamen, is zeer de vraag. ${ }^{45}$ Aangezien de maatregel ten laste van de boedel wordt opgelegd en artikel 33 WED de niet-nakoming van de verplichtingen van artikel 16 WED niet met zoveel woorden noemt, kan worden betwijfeld of vervolging van de erfgenaam voldoende voorzienbaar zou zijn. Een dergelijke strafbaarstelling doet bovendien denken aan vererving van strafrechtelijke aansprakelijkheid: het aan de nabestaanden gemaakte verwijt vindt zijn oorsprong in gedragingen van de overledene. Uit de rechtspraak volgt bovendien dat het in artikel 33 WED genoemde misdrijf alleen gepleegd kan worden door degene tot wie de maatregel is gericht. ${ }^{46}$ Aan te nemen valt dat dit niet de erfgenamen zijn. Om deze redenen kan worden verondersteld dat artikel 33 WED buiten toepassing blijft in het geval van niet-naleving van de maatregel door erfgenamen.

\subsection{Ontnemingsmaatregel}

De dood van de betrokkene voorafgaand aan of gedurende de ontnemingsprocedure staat in die procedure aan de ontvankelijkheid van het openbaar ministerie in de weg. ${ }^{47}$ Ingeval de verplichting tot betaling aan de Staat van een bedrag waarop het wederrechtelijk verkregen voordeel is gesteld onherroepelijk is, maar de verdachte overlijdt voordat de strafzaak tot een onherroepelijke veroordeling heeft geleid, dan vervalt de opgelegde ontnemingsmaatregel met de niet-ontvankelijkverklaring van de officier van justitie in de hoofdzaak op grond van artikel 511i Sv van rechtswege. Artikel 6:1:21 Sv opent wel de deur voor de executie van de ontnemingsmaatregel, indien deze met de strafzaak onherroepelijk is geworden voordat de betrokkene is overleden. Aangenomen wordt dat artikel 6 lid 2 EVRM zich hiertegen niet verzet. ${ }^{48}$ Dat lijkt ons juist. De betrokkene aan wie de maatregel is opgelegd, is ten tijde van de oplegging immers reeds onherroepelijk veroordeeld. Voor die persoon is het vermoeden van onschuld dus 'weerlegd' doordat zijn schuld is bewezen. ${ }^{49}$ De erfgenamen worden daarnaast niet strafrechtelijk aansprakelijk gehouden. Er is sprake van een onherroepelijke maatregel, die niet ten laste van de nabestaanden wordt opgelegd, maar enkel ten uitvoer wordt gelegd op de nalatenschap. Uit de Straatsburgse rechtspraak lijkt te

45. Op grond van art. 1 onder $5^{\circ}$ in verbinding met art. 2 lid 5 WED betreft dit economisch delict een misdrijf.

46. Vgl. HR 12 november 1968, ECLI:NL:HR:1968:AB4584, NJ 1969/104

47. Dit rechtsgevolg vermeldt de wet niet met zoveel woorden, maar de Hoge Raad heeft het uit de wetsgeschiedenis afgeleid, zie HR 18 maart 2008, ECLI:NL:HR:2008:BC6732. Zie daarvoor al HR 17 juni 1997, ECLI:NL:HR:1997:ZD0760, DD 97.303.

48. M.J. Borgers, De ontnemingsmaatregel (diss. Tilburg), Den Haag: Boom juridische uitgevers 2001, p. 184 en Den Hartog 1998, p. 119, 121-122.

49. Uiteraard kan de oplegging van de ontnemingsmaatregel nog wel om de inhoud van die beslissing in strijd komen met art. 6 EVRM, bijvoorbeeld als daarbij schuld wordt vastgesteld aan een feit waarvan de overledene is vrijgesproken, vgl. EHRM 1 maart 2007, nr. 30810/03, NJ 2007/349 m.nt. Borgers (Geerings/Nederland). kunnen worden afgeleid dat het EVRM hieraan inderdaad niet in de weg staat. ${ }^{50}$

Door de tenuitvoerlegging van de ontnemingsmaatregel kunnen erfgenamen in een nadelige positie komen te verkeren, bijvoorbeeld indien een negatieve nalatenschap ontstaat door de toegepaste maatregel. Zij kunnen wel overeenkomstig artikel 6:6:26 lid $1 \mathrm{~Sv}$ om vermindering of kwijtschelding verzoeken. ${ }^{51}$ Daartoe zou de rechter volgens Borgers moeten overgaan, indien de betalingsverplichting ertoe leidt dat de erfgenaam zijn reeds aanwezige vermogen moeten aanspreken. ${ }^{52}$ De wet dwingt daartoe evenwel niet, en evenmin sluit de wet de toepassing van gijzeling uitdrukkelijk uit indien erfgenamen niet tot betaling overgaan. ${ }^{53}$ Weigeren erfgenamen te betalen, dan ligt naar ons inzicht civielrechtelijk verhaal (beslag en executie) in de rede.

\subsection{Onttrekking aan het verkeer}

De maatregel van onttrekking aan het verkeer kan door de rechter worden bevolen om voorwerpen waarvan het ongecontroleerde bezit in strijd met de wet of met het algemeen belang is, uit het maatschappelijke verkeer te verwijderen. Aan het aan deze maatregel ten grondslag liggende belang de maatschappij tegen gevaarlijke voorwerpen te beschermen, komt ook na het overlijden van de verdachte nog gewicht toe. Artikel 36b Sr geeft een opsomming van de gevallen waarin de maatregel kan worden opgelegd: bij een veroordeling (al dan niet met oplegging van straf), bij een einduitspraak waarbij ondanks een vrijspraak of ontslag van alle rechtsvervolging wordt vastgesteld dat een strafbaar feit is begaan, bij een strafbeschikking en bij afzonderlijke beschikking. Eindigt de strafzaak door het overlijden van de verdachte in de niet-ontvankelijkverklaring van het openbaar ministerie, dan kan bij die einduitspraak dus niet de onttrekking aan het verkeer worden bevolen. Gelet op het beschermingskarakter van de maatregel en de onwenselijkheid gevaarlijke voorwerpen in de maatschappij terug te brengen, ligt het voor de hand dat het openbaar ministerie in dat geval de onttrekking aan het verkeer bij afzonderlijke rechterlijke beschikking op grond van artikel $36 \mathrm{~b}$ lid 1 sub $4^{\circ} \mathrm{Sr}$ vordert. ${ }^{54}$

Die route kent wel enige hobbels. Weliswaar wordt de afzonderlijke procedure niet beschouwd als een daad van vervolging of een criminal charge, maar de oplegging van deze maatregel vergt wel de vaststelling van een strafbaar feit. ${ }^{55}$ De rechter die zich moet uitspreken over

50. EHRM 10 april 2012, nr. 20496/02, par. 53-54 (Silickiene/Litouwen), waarin het EHRM het reparatoire karakter van de sanctie van belang achtte.

51. Tot 1 januari 2020 (Stb. 2017, 82) was deze regeling terug te vinden in art. 557b lid 2 Sv.

52. Borgers 2001, p. 181-182.

53. Art. 6:6:25 Sv.

54. Zie Kamerstukken II 1954/55, 4034, nr. 3, p. 11; HR 28 januari 1986, ECLI:NL:HR:1986:AC9208, NJ 1986/551 en HR 6 november 2001, ECLI:NL:HR:2001:AD4430, NJ 2002/173.

55. Zie HR 8 september 1987, ECLI:NL:HR:1987:AC1218, NJ 1988/453, waarin is bepaald dat in een dergelijke procedure art. 6 EVRM van toepassing is nu sprake is van het vaststellen van burgerlijke rechten en 
een tot onttrekking strekkende vordering zal daarbij een weg moeten vinden om de onschuldpresumptie van de overledene toch in acht te nemen. ${ }^{56}$ Een schuldvaststelling door de onttrekkingsrechter aan het feit waarvoor de overleden verdachte voor zijn dood werd vervolgd, is in beginsel niet toegestaan. Wel kunnen verdenkingen worden geuit, of kan een strafbaar feit worden geconstateerd waarvan in het midden blijft of het de verdachte is geweest die het feit beging. ${ }^{57}$

\section{Op zoek naar een patroon}

De artikelen $69 \mathrm{Sr}$ en 6:1:21 Sv spiegelen de lezer een eenvoudig systeem voor: een overledene kan niet meer in een strafprocedure worden betrokken en de dood zet een punt achter een lopende strafvervolging en, behoudens de ontnemingsmaatregel, achter de executiefase van het strafgeding. De juridische werkelijkheid is echter complexer. In deze bijdrage is in kaart gebracht welke verschillende straffen en maatregelen na overlijden kunnen worden opgelegd of tenuitvoergelegd. Aan de hand hiervan wordt in deze paragraaf nader beschouwd of het Nederlandse strafprocesrecht wat betreft de straf(proces)rechtelijke situatie na overlijden een coherente en voldoende doordachte regeling kent. Daartoe staan we allereerst stil bij de voornoemde hoofdregel uit de artikelen $69 \mathrm{Sr}$ en 6:1:21 Sv. Spreken de straf(proces)rechtelijke consequenties die aan overlijden worden verbonden nog steeds aan? Vervolgens wordt bezien of het op het eerste gezicht 'bont ogende

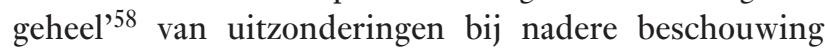
toch een coherent systeem vormen.

Dat het overlijden van een verdachte in beginsel in de weg staat aan (verdere) vervolging is in feite onomstreden. Zolang de procedure zich in een fase bevindt dat de verdachte - indien hij nog in leven zou zijn - verdedigingsrechten zou kunnen uitoefenen, lijkt een andere lijn ons nauwelijks verdedigbaar. Het in dat geval doorzetten van vervolging en bestraffing doet dan tekort aan het recht van de verdachte op een eerlijk proces. Het is de vraag of de kaarten anders liggen als het strafproces is beland in een fase waarin de verdediging geen actieve rol meer heeft. Naar geldend recht maakt het niet uit in welke fase van de procedure de verdachte overlijdt. Alleen als hij overlijdt tussen de uitspraak en het instellen van een rechtsmiddel daartegen zal die uitspraak wellicht onherroepelijk worden. In alle andere gevallen is het openbaar ministerie niet-ontvankelijk. Zo belet de dood van de verdachte, zelfs als hij in eerste aanleg én in hoger beroep is veroordeeld en zijn cassatieberoep volgens de advocaat-generaal bij de Hoge Raad geen

verplichtingen. Vgl. verder HR 3 april 2007, ECLI:NL:HR:2007:AZ8349; HR 18 maart 2014, ECLI:NL:HR:2014:649 en Bemelmans 2018, p. $429-431$

56. Zie hierover nader Bemelmans 2018, p. 429-431.

57. Zie bijv. HR 23 juni 2009, ECLI:NL:HR:2009:BI2289, NJ 2009/365.

58. Aldus De Hullu 2018, p. 118. kans van slagen heeft, dat zijn veroordeling in stand blijft. ${ }^{59}$ Onder meer Van Veen en Remmelink hebben in het verleden betoogd dat het karakter van de cassatieprocedure zich ervoor leent om na overlijden van de verdachte in dat stadium van het strafgeding toch een inhoudelijke uitspraak te doen. ${ }^{60} \mathrm{Wij}$ zijn daar geen voorstander van. Weliswaar zou het onherroepelijk worden van de veroordeling en de eventueel toegewezen vordering voor het slachtoffer en de benadeelde partij een positieve betekenis kunnen hebben, ${ }^{61}$ maar daar staat tegenover dat de cassatieprocedure, meer dan vroeger, een inbreng van de verdediging vergt. Nu verdere inbreng van de verdediging door het overlijden van de verdachte niet meer te verwachten valt, zal met het oog op de verdedigingsrechten van de verdachte een eventuele uitzondering op de niet-ontvankelijkheid van het openbaar ministerie in de cassatieprocedure slechts in een zeer beperkt aantal gevallen voorstelbaar zijn. ${ }^{62} \mathrm{Bij}$ de keuze van de wetgever de dood van de verdachte als vervolgingsbeletsel aan te merken, past het beter om vast te houden aan de eenduidige regeling waarin de dood tot aan de einduitspraak van de strafrechter de vervolging belet. ${ }^{63}$

In paragraaf 4 is besproken welke straffen en maatregelen overblijven na het overlijden van de verdachte of veroordeelde. Kenmerkend aan dat sanctiepalet is dat het telkens gaat om vermogenssancties. Deze sancties beschermen belangen die ook na het overlijden van de verdachte of veroordeelde overeind blijven. Het gaat om de bescherming van de maatschappij tegen gevaarlijke voorwerpen (onttrekking aan het verkeer), het zo veel mogelijk herstellen van de gevolgen van het begane delict (de tenuitvoerlegging van de ontnemingsmaatregel en de maatregel tot herstel van een wederrechtelijke situatie) en/of voorkomen dat misdaad - ook voor de erfgenamen van de dader - loont (de verbeurdverklaring in de WED, de tenuitvoerlegging van de ontnemingsmaatregel en wellicht in mindere mate de maatregel tot herstel). Daarmee onderscheiden deze vermogenssanc-

59. Zie bijv. HR 17 september 2019, ECLI:NL:HR:2019:1083.

60. Van Veen 1972 en J. Remmelink, Mr. D. Hazewinkel-Suringa's Inleiding tot de studie van het Nederlandse strafrecht, Arnhem: Gouda Quint 1996, p. 610.

61. Vgl. in dit verband SJC 13 maart 2019, 481 Mass. 582 (Commonwealth/Aaron J. Hernandez), waarin de Supreme Judicial Court van Massachusetts mede met het oog op de belangen van slachtoffers oordeelde dat de dood van de verdachte, een Amerikaanse topsporter, hangende zijn hoger beroep niet meer leidt tot dismissal van de zaak, maar tot het einde van het appel. De schuldigverklaring door de jury bleef hierdoor in stand.

62. Gedacht moet dan vooral worden aan het overlijden van de verdachte na het verstrijken van de termijn voor het indienen van een Borgersbrief, waarin de verdediging op de voet van art. 439 lid 5 Sv kan reageren op de conclusie van de advocaat-generaal. Al zou de benadering eveneens voorstelbaar zijn wanneer de verdachte overlijdt na sluiting van het onderzoek in eerste aanleg of in hoger beroep, maar voordat in die instantie uitspraak is gedaan. Nadeel daarvan is dat de verdachte niet toekomt aan het aanwenden van een rechtsmiddel, evenals het geval lijkt te zijn als de verdachte tussen de einduitspraak en het aanwenden van een rechtsmiddel sterft.

63. Die benadering stemt overeen met de wijze waarop bijvoorbeeld de vervolgingsverjaring door de strafrechter wordt onderzocht en - óók in cassatie - tot op de dag van de uitspraak wordt verwerkt. 
ties zich van de commune vermogensstraffen, de geldboete en de verbeurdverklaring, die niet na overlijden kunnen worden opgelegd of tenuitvoergelegd. Het strafkarakter van deze laatste twee sancties is een sterk argument om ze niet aan overledenen op te leggen of op hun nalatenschap te executeren. Alhoewel de rechtspraak van het EHRM voor dit laatste een zekere ruimte laat, ligt in het ons sanctiestelsel kenmerkende onderscheid tussen straffen en maatregelen besloten dat de straf persoonlijk is, een reactie vormt op een strafbaar feit en de schuld van de bestrafte daaraan, en doelen als vergelding en speciale preventie nastreeft. ${ }^{64}$ Daarbij past in het algemeen slecht om nabestaanden met vermogensstraffen op te zadelen. Er bestaat in onze ogen geen goede grond het stelsel op dit punt te wijzigen.

Aan de oplegging of tenuitvoerlegging van andere vermogenssancties na overlijden bestaat als gezegd nog wel behoefte. ${ }^{65}$ Maar ook in het kader van die uitzonderingen dienen het recht op een eerlijk proces, de onschuldpresumptie en het beginsel 'geen straf zonder schuld' voldoende in acht te worden genomen. Doordat de ontnemingsmaatregel wordt opgelegd in een afzonderlijke procedure die aan maatstaven voor een eerlijk proces behoort te voldoen, bestaat bijvoorbeeld weinig ruimte om na overlijden de ontnemingsmaatregel nog op te leggen aan nabestaanden, ${ }^{66}$ al lijkt de wens daartoe soms wel aanwezig. ${ }^{67}$ Aan de mogelijkheid tot tenuitvoerlegging en de wens tot oplegging van de ontnemingsmaatregel ligt dezelfde gedachte ten grondslag als aan de bijzondere regeling van de verbeurdverklaring in de artikelen 13 en 16 WED, namelijk dat misdaad ook voor nabestaanden van een overleden dader niet mag lonen. Deze regeling wijkt af van het commune strafrecht, waarin de oplegging en executie van de verbeurdverklaring niet mogelijk zijn. Een goede reden voor deze uitzonderingspositie van het economisch strafrecht ontbreekt.

Dat roept de vraag op of de regeling van de WED moet komen te vervallen of moet worden veralgemeniseerd. Aan de in de WED voorziene mogelijkheid bestaat naar ons inzicht wel behoefte. ${ }^{68}$ Als onder de verdachte niet-

64. Zie bijv. De Hullu 2018, p. 6 en 118 en C. Kelk \& F. de Jong, Studieboek materieel strafrecht, Deventer: Wolters Kluwer 2019, p. 553. Het gaat hier om een grove schets van het onderscheid. Zie voor dogmatische beschouwingen over de (on)zin daarvan o.a. D. van der Landen, Straf en maatregel, Arnhem: Gouda Quint 1992 en Kooijmans 2002, p. 9 e.v.

65. Vgl. Kooijmans 2002, p. 274 over de mogelijkheid tot onttrekking aan het verkeer bij afzonderlijke beschikking.

66. Een niet op een veroordeling gebaseerde ontnemingsmaatregel brengt bovendien nog weer eigen complicaties met zich, zie EHRM (GK) 28 juni 2018 , nrs. 1828/06 e.a. (G.I.E.M. e.a./Italië).

67. $\mathrm{Vgl}$. het ingetrokken voorstel voor een 'Wet confiscatie crimineel vermogen', Kamerstukken II 1993/94, 23 704, waarmee onder meer de confiscatie van wederrechtelijk verkregen vermogen van een overledene werd beoogd

68. Zie ter illustratie de beslagzaak HR 4 juni 2019, ECLI:NL:HR:2019:837, NJ 2019/244 en vooral de door de Hoge Raad gevolgde conclusie van A-G Harteveld (onderdeel 3.8), waarin hij nagaat of de in art. 94 Sv genoemde strafvorderlijke belangen in een strafzaak waarin de verdachte is overleden de voortduring van het beslag op geldbedragen gevaarlijke, maar wel waardevolle goederen in beslag zijn genomen onder omstandigheden die wijzen op afkomst uit misdrijf strookt het niet met het rechtsgevoel die goederen aan de erfgenamen terug te geven omdat de verdachte voortijdig overlijdt. In zoverre is het nodige te zeggen voor overheveling van deze regeling uit de WED naar het Wetboek van Strafrecht. Betwijfeld kan echter worden of de verbeurdverklaring, een sanctie met een strafkarakter, de meest aangewezen sanctiemodaliteit is voor het beoogde doeleinde. Dat strafkarakter en de doelen die met de verbeurdverklaring in het algemeen worden nagestreefd, verhouden zich niet goed met de oplegging daarvan als degene die het feit zou hebben begaan reeds is overleden. De indruk dat de erfgenamen een straf wordt opgelegd, zou onjuist zijn en moet dus worden vermeden. Vanuit het oogpunt van de systematiek van het sanctiestelsel is er wat ons betreft meer voor te zeggen om de aanvullende mogelijkheid tot verbeurdverklaring uit de WED te schrappen en een dergelijke sanctie als commune maatregel vorm te geven. ${ }^{69}$ Met die maatregel zouden bij een verdachte in beslag genomen voorwerpen ten bate van de Staat vallen indien de verdachte is overleden en de rechter het aannemelijk acht dat deze goederen uit misdrijf afkomstig zijn. Het beoogde doel van deze sanctie is bovendien vergelijkbaar met de reparatoire grondslag van de ontnemingsmaatregel, hetgeen eveneens pleit voor het maatregelkarakter ervan. Evenals in het kader van de onttrekking aan het verkeer bij afzonderlijke beschikking, kan de schuldvaststelling van de verdachte aan een strafbaar feit bij de oplegging van een dergelijke maatregel achterwege blijven. Voldoende is dat aannemelijk is dat het desbetreffende voorwerp uit misdrijf afkomstig is.

De verschillen met de bestaande regeling van de verbeurdverklaring van de artikelen 13 en 16 WED zouden zijn dat het een maatregel betreft die ter zake van alle strafbare feiten kan worden toegepast. Van de onttrekking aan het verkeer zou de maatregel verschillen doordat niet alleen gevaarlijke goederen, maar ook bijvoorbeeld geldbedragen kunnen worden onttrokken aan de nalatenschap respectievelijk het vermogen van de erfgenamen. Bovendien zou de maatregel, anders dan de commune verbeurdverklaring en de ontnemingsmaatregel, kunnen worden opgelegd terwijl geen onherroepelijke veroordeling heeft plaatsgehad. Door de oplegging ten slotte afhankelijk te stellen van de aannemelijkheid dat met betrekking tot een in beslag genomen goed door wie dan ook een strafbaar feit is begaan, kan de onschuldpresumptie worden gerespecteerd.

kunnen rechtvaardigen en die vraag ontkennend beantwoordt. Vgl. ook HR 7 januari 2020, ECLI:NL:HR:2020:9, NJ 2020/47 over verbeurdverklaring van geldbedragen die niet aan een bewezenverklaard delict konden worden gerelateerd.

69. Vgl. Kooijmans 2002, p. 274: ‘De vermeende verwijtbaarheid is daarbij [bij de vernietiging van een vuurwapen] niet aan de orde en de achterliggende gedachte van artikel $69 \mathrm{Sr}$ verzet zich dan ook niet tegen de oplegging van een - niet-bestraffende sanctie die strekt tot opheffing van de ongewenste situatie.' 
Met de wenselijkheid om de hiervoor genoemde maatregelen ook na overlijden nog te kunnen toepassen, strookt vanzelfsprekend niet dat deze maatregel vanwege het overlijden van de verdachte komt te vervallen. De in artikel 6:1:21 Sv voor de ontnemingsmaatregel voorziene uitzondering op het verval van executie, zou mutatis mutandis ook dienen te gelden voor in ieder geval de onttrekking aan het verkeer en de door ons voorgestelde maatregel. ${ }^{70} \mathrm{Wel}$ zal bij dit alles moeten worden bedacht hoe in het kader de oplegging en executie van deze maatregel de positie voor de erfgenamen kan worden vormgegeven op een wijze die recht doet aan hun door onder meer artikel 1 Eerste Protocol EVRM beschermde aanspraak op de nalatenschap.

\section{Conclusie}

Het overlijden van een verdachte of veroordeelde heeft straf(proces)rechtelijke gevolgen. Het uitgangspunt van de wetgever van 1886 dat het overlijden de (verdere) strafvervolging belet, staat nog altijd overeind. Op de hoofdregels dat na het overlijden van de verdachte geen straffen en maatregelen kunnen worden opgelegd en dat strafrechtelijke sancties niet langer tenuitvoergelegd kunnen worden, zijn voor verschillende vermogenssancties uitzonderingen gemaakt. Aan een aantal van de sanctiemodaliteiten die nog openstaan na het overlijden ligt de gedachte ten grondslag dat misdaad niet mag lonen en dat nabestaanden niet mogen profiteren van onrechtmatige gedragingen van de overledene. Die grondgedachte onderschrijven wij, maar op de wijze waarop de wetgever daaraan invulling heeft gegeven is naar ons oordeel een en ander aan te merken. Met name voor de afzonderlijke regeling van de verbeurdverklaring in de WED bestaan geen goede redenen, terwijl de toepassing daarvan ook op gespannen voet kan staan met de onschuldpresumptie. Wij stellen voor om deze regeling af te schaffen en een commune maatregel te introduceren waarmee kan worden voorkomen dat van misdrijf afkomstige in beslag genomen goederen aan de erfgenamen van de overleden verdachte of veroordeelde ten deel vallen, zonder dat de onschuldpresumptie van de overledene in het geding komt. Ondanks het overlijden van de betrokkene en het daarmee onlosmakelijk verbonden einde van schuldvaststelling en strafoplegging, kunnen op die manier sommige strafrechtelijke sancties toch nog voortleven. 